\title{
FLORISTIC COMPOSITION AND MEDICINALLY IMPORTANT PLANTS IN THE UNDERSTOREY OF THE TROPICAL DRY MIXED EVERGREEN FOREST AT THE HURULU RESERVE OF SRI LANKA
}

\author{
S.M. SOLANGAARACHCHI \\ Department of Botany, University of Kelaniya, Kelaniya.
}

\begin{abstract}
AND
B.M.S. PERERA

Institute of Fundamental Studies, Kandy.

(Date of receipt . : 20 November 1992)

(Date of acceptance : 23 August 1993)
\end{abstract}

\begin{abstract}
A study of the species composition and a quantitative survey of the understorey (diameter at breast height, DBH $<10 \mathrm{~cm}$ ) at a selected site of the Hurulu forest reserve, a Tropical Dry Mixed Evergreen forest, were carried out. Eighty one species representing 73 genera and 37 families were recorded. About $6 \%$ of the species were found to be endemic and $61 \%$ were found to be of medicinal importance. The density and the percentage frequency of the species were presented in two categories separately. Plants of DBH $<10 \mathrm{~cm}$ and height $>1 \mathrm{~m}$ were included in category 1 whereas the plants of DBH $<10 \mathrm{~cm}$ and height $<1 \mathrm{~m}$ were included in category 2. Glycosinis angustifolia: attained the highest density of 163 per $100 \mathrm{~m}^{2}$ and the highest percentage frequency of 71 in category 1 . In category 2 the same species reached the highest density of 33 and the highest frequency of 20 . Therefore it was concluded that Glycosmis angustifolia. was the most ecologically important species in the understorey of the Tropical Dry Mixed Evergreen forest.
\end{abstract}

Key words: Dry zone forest, floristic composition, understorey.

\section{INTRODUCTION}

It has been reported that about $38 \%$ of the total area of the island is covered with forests $^{1}$. Approximately $84 \%$ of the forest cover is found in the dry zone which covers $77 \%$ of the island. The classification of forest types based on floristic and physiognomic features, has been done by many authors. ${ }^{2-8}$ In the present study the classification introduced by Andrews ${ }^{6}$ was adopted. Accordingly, the Hurulu forest reserve located in the dry zone is classified as a Tropical Dry Mixed Evergreen forest. It is secondary in nature owing to past interference by man. ${ }^{9}$

So far the forests of the dry zone lowlands of Sri Lanka have received less attention as compared to wet zone forests. ${ }^{10-12}$ Some available studies have been restricted to different locations of the dry zone. For example, Polonnaruwa sanctuary ${ }^{9}$; Udawalawe national park ${ }^{13}$; Ritigala ${ }^{14}$; Wilpatthu national park ${ }^{15}$ and Hurulu forest reserve near Sigiriya. Most of these surveys however were confined to the studies of the floristic composition and quantitative analyses of the trees of which diameter at breast height (DBH) is more than $10 \mathrm{~cm}$ in the canopy layers. Generally, the Tropical Dry Mixed 
Evergreen forests are smaller in stature and floristically and structurally less complex than wet tropical forests. The canopy is somewhat discontinuous and approximate height is $15-18 \mathrm{~m}$. The canopy consists of Manilkara hexandra, Diospyros ebenum, Berrya cordifolia, Syzygium cumini, Pterospermum canescens, Schleichera oleosa, Chloraxylon swietenia and the sub canopy consists of Dimocarpus longan, Vitex altissima, Drypetes sepiaria, Adina cordifolia and Alseodaphne semecarpifolia. ${ }^{16}$ Some other aspects such as the amount of litterfall and its seasonal variation and wood input have also been studied in the Hurulu forest reserve. ${ }^{17}$ Consequently, in the literature, there is a dearth of studies on the understorey of the forests of the dry zone lowlands. The understorey of a forest is as important as its canopy. It prevents soil erosion, provides shelter and space for the forest fauna, facilitates nutrient cycling and, ensures most importantly, the regeneration of the forest.

Peeris ${ }^{18}$ has reported that about $4 \%$ of the country's endemic flora comprising 34 species occurs in the Dry Zone. In the subsequent years to this analysis, deforestation may have led to the extiction probably of some indigenous species, inclusive of one or more of these endemics.

Against this information, a survey was carried out of the understorey at a selected site at Hurulu forest reserve of a Tropical Dry Mixed Evergreen forest during the period from April to September in 1990 (i.e. during the dry season). Its main objectives were, to determine the species composition of the understorey and to carry out a quantitative survey of the composition. The endemicity and medicinal importance of its species were also recorded. In the present study plants of $D B H<10 \mathrm{~cm}$ were considered as the understorey.

\section{METHODS AND MATERIALS}

The study site: The study was conducted at a site within the Hurulu forest reserve situated in the Matale district. The site lies $2 \mathrm{~km}$ from the Sigiriya Rock and covers an area of approximately 35 ha. The northern, eastern, southern and western boundaries of the forest are marked by two chenas, Pidurangala village, Pidurangala temple and the Ihalagama tank respectively. A small ancient tank (Pansala tank) is located within the forest. The two main pathways leading to the site are Sigiriya-Pidurangala road, which runs from south to north-east, and Habarana-Pidurangala road, which runs from north to south.

Species composition: The collection of plant specimens $(\mathrm{DBH}<10 \mathrm{~cm})$ from the study area were pressed for two weeks. The sampling was carried out at three different times to ensure it represented nearly all the species that occured. The specimens present were first treated with $1 \%(\mathrm{w} / \mathrm{v})$ mercuric chloride $\left(\mathrm{HgCl}_{2}\right)$ and finally mounted on herbarium sheets. The morphological characters were studied and they were then identified by comparing them with those represented in the Herbarium, Department of Botany, University of Kelaniya, and in the National 
Herbarium, Peradeniya. The identifications were confirmed by reference to the Flora of Ceylon by Trimen ${ }^{19}$ and to its revised edition by Dassanayake and Fosberg. ${ }^{20}$ The identified species were then checked both for their endemicity and their medicinal importance. The data of the latter aspect were obtained by consulting the parts of medicinal plants used in Ceylon by Jayaweera, ${ }^{21}$ as well as the specimens kept at The Ayurvedic Research Institute of Sri Lanka.

Quantitative survey of the vegetation: An undisturbed representative area of about $10 \mathrm{ha}$ of the forest was selected for the quantitative survey of the vegetation. This survey was carried out in ten randomly selected replicate sample plots (quadrats) of $10 \mathrm{~m} \times 10 \mathrm{~m}$, each of which was subdivided into 100 units.

The quantitative analysis was carried out under two separate categories. Plants of DBH $<10 \mathrm{~cm}$ and height $>1 \mathrm{~m}$ were included in the category 1 and the plants of DBH $<10 \mathrm{~cm}$ and height $<1 \mathrm{~m}$ were included in the category 2 . The number of individuals of each species was counted in each subdivision, and the Density of each species per $100 \mathrm{~m}^{2}$ was estimated by totalling the counts in each subdivision of the sample plot. ${ }^{22}$ The presence or absence of each species in each subdivision was observed, and the percentage frequency of each species was estimated by calculating the percentage of subdivisions in which each species was present. In this study rooted frequency was considered. ${ }^{22}$ Relative density and relative frequency values were calculated as indicated below. ${ }^{23}$

Relative density of species $\mathrm{A}$ in sample plot $\mathrm{X}$

Relative frequency of species $\mathrm{A}$ in $\quad=$ sample plot $\mathrm{X}$
Stand density of species A in sample plot $\mathbf{X}$

Total stand density of all species in sample plot $X$

Frequency of species $\mathrm{A}$ in sample plot X

Sum of frequencies for all species in sample plot $\mathrm{X}$ $\times 100$ $\mathbf{x} 100$

\section{RESULTS}

Tables $1 \mathrm{a}$ and $1 \mathrm{~b}$ show the species composition of all species $(\mathrm{DBH}<10 \mathrm{~cm})$, their life forms, endemicity and medicinal importance. A total of 81 species belonging to 73 genera and 37 families were recorded. About $11 \%$ of the species belonged to the family Rubiaceae, $8.6 \%$ to the Euphorbiaceae and $8.6 \%$ to the Rutaceae. The majority of species $(46 \%, 37$ species) found in the understorey belonged to tree forms. Only a very few species i.e. $15 \%$ ( 12 species) were herbs. The understorey also consisted of eight (10\%) climbers and four (5\%) liana species. 
About $6 \%$ (five species) were found to be endemic. They are Atalantia zeylanica, Drypetes gardneri, Ixora thwaitesii, Tricalysia enthrospora and Vernonia zeylanica. These include three tree species and two shrub species. About $61 \%$ of the species (49 species) were found to be medicinally important. Some species were found to be deciduous. They are Chloroxylon sweitenia, Vitex altissima, Grewia polygama and Pterospermum suberifolium. The evergreen species were Manilkara hexandra and Diospyros spp. Some armed with spines were also found. e.g. Maytenus emarginata, Canthium parvifolium, Atalantia zeylanica, Toddalia asiatica and Randia dumetorum.

Table 1a: Floristic composition of the understorey vegetation (DBH $<10 \mathrm{~cm}$ ) of the studied area of a Tropical Dry Mixed Evergreen Forest. $(\mathrm{T}=$ Tree, $\mathbf{S}=$ Shrub, $\mathbf{H}=$ Herb, $\mathbf{C}=$ Climber, $\mathbf{L}=$ Liana, $\mathbf{L C}=$ Large Climber, CS = Climbing Shrub, $T w=$ Twiner, $*=$ endemic and $+=$,medicinally important).

\begin{tabular}{|c|c|c|c|}
\hline Family and Species & Sinhala name & Tamil name & Life form \\
\hline Acanthaceae & Samadana & & \\
\hline (1) Blepharis edulis Pers. & & & $\mathrm{C}^{+}$ \\
\hline $\begin{array}{l}\text { (2) Ecbolium ligustrinum (Vahl) } \\
\text { Vollesene }\end{array}$ & & & $\mathrm{H}$ \\
\hline \multicolumn{4}{|l|}{ Annonaceae } \\
\hline (1) Miliusa indica Leschen. & & & S \\
\hline (2) Polyalthia spp. & & & $\mathrm{T}$ \\
\hline (3) Polyalthia korinti (Dunal) Thw. & Ulkenda & Uluvintai & $\mathrm{T}$ \\
\hline $\begin{array}{l}\text { (4) Polyalthia suberosa (Roxb.) Thw. } \\
\text { Asteraceae }\end{array}$ & Kalati & & $\mathrm{T}$ \\
\hline (1) Elephantopus scaber L. & Eth Adi & Anaichuvadi & $\mathrm{H}$ \\
\hline (2) Microglossa zeylanica Arn. & & & $\mathrm{H}$ \\
\hline (3) Vemonia anthelmintica (L.) Wild & Sanninayan & Kattucheragham & $\mathrm{H}$ \\
\hline (4) Vemonia zeylanica (L.) Less. & Pupula & Kuppilai & $S^{*}$ \\
\hline \multicolumn{4}{|l|}{ Asclepiadaceae } \\
\hline (1) Bidaria spp. & & & $\mathrm{C}$ \\
\hline $\begin{array}{l}\text { (2) Tylophora tenuissima (Roxb.) } \\
\text { White \& Arn. }\end{array}$ & & & $\mathrm{C}$ \\
\hline $\begin{array}{l}\text { (3) Sarcostemma brunonianum Wight } \\
\text { \& Arn. }\end{array}$ & Muwakiriya & Kodikkalli & $\mathrm{C}^{+}$ \\
\hline Boraginaceae & & & \\
\hline (1) Ehretia buxifolia Roxb. & Hin-tambala & & $\mathbf{S}$ \\
\hline (2) Cordia spp. & & & $\mathbf{H}$ \\
\hline Capparidaceae & & & \\
\hline (1) Capparis spp. & & & $S$ \\
\hline
\end{tabular}


Table 1a Contd.

Family and Species Sinhala name

Tamil name

Life form

Celastraceae

(1) Maytenus emarginata

(2) Elaeodendron glaucum (Rottb.) Neralu Pers.

[Cassine glauca (Rottb.) Kumtze]

Convolvulaceae

(1) Angyreia osyrensis (Roth.) Choisy Dumbada

$\mathrm{LC}^{+}$ Cucurbitaceae

(1) Bryoniopsis laciniosa $\mathrm{L}$.

Kemwel

$\mathrm{C}^{+}$

Cyperaceae

(1) Scleria lithosperna (L.) Sw.

H

Dioscoreaceae

(1) Trichopus zeylanicus Gaertn. Bimpol H

Ebenaceae

(1) Diospyros spp.

(2) Diospyros ovalifolia Wight

Kunumella

$\mathrm{T}$

Euphorbiaceae .

(1) Croton officinalis

(2) Dimorphocalyx glabellus Thw.

Weliwenna

(3) Drypetes gardneri Thw.

Etaweera

(4) Drypetes sepiaria (Wight \& Arn.)

Weera

(5) Flueggea leucopyrus Willd.

Hin-katupila

(6) Mallotus albus Roxb.

Bu-kenda

(7) Phyllanthus polyphyllus Willd.

Kuratiya

$\begin{array}{ll} & \text { S } \\ \text { Anaithadichchi } & \text { T }\end{array}$

Fabaceae

(1) Albizia amara (Roxb.) Boivin Iha

(2) Bauhinia tomentosa L

Iha
Pethan
Ehala
Thekil

(3) Cassia fistula L.

Iha
Pethan
Ehala
Thekil

(4) Derris uliginosa Willd.

Iha
Pethan
Ehala
Thekil

Thenthuki

Weerai

Weeramaram

Irubulai

(5) Painteria nitida (Vahl) Kosterm.

Flacourtiaceae

(1) Flacourtia indica

Usil

Thiruvathi

Thirukonrai

H

$\mathrm{T}$

Hippocrateaceae

(1) Salacia indica Wight

Himbutu wel

(2) Salacia reticulata Wight

Kothala himbutu

$\mathrm{S}^{+}$

$T^{+}$

$\mathrm{T}^{*}$

$\mathrm{T}^{+}$

$\mathrm{S}^{+}$

$T$

$\mathrm{T}^{+}$

Hypoxidaceae

(1) Curculigo orchioides Gaertn. $\quad$ Bim tal Nilapannai $\quad \mathrm{H}^{+}$

Lauraceae

(1) Alseodaphne semecarpifolia Nees

Wewarana

Yaveranai

$\mathbf{T}^{+}$

Loganiaceae

(1) Strychnos nux-vomica L.

Goda Kaduru

Kangirei 
Table 1a Contd.

Family and Species

Sinhala name

Tamil name

Life form

Malphigiaceae

(1) Hiptage benghalensis $\mathrm{L} . \quad$ Puwak gediya $\quad \mathrm{L}^{+}$

Malvaceae

(1) Hibiscus spp.

$\mathbf{T}$

Melastomataceae

(1) Memecylon umbellatum Burm. f: Dodan-wenna

Alli

$\mathbf{T}^{+}$

Meliaceae

(1) Azadirachta indica A. Juss.

Kohomba

Vermbu

$\mathbf{T}^{+}$

!2) Aglaia roxburghiana Wight \& Arn. Kiri kon

Kannikkombu

$T^{+}$ (Miq).

Menispermaceae

(1) Cissampelos pareira $\mathrm{L}$.

Diya mitta

Appatta

$\mathrm{Tw}^{+}$

Moraceae

(1) Streblus taxoides (Heyne) Kurz

Myrtaceae

(1) Syzygium cumini (L) Skeels
Ochnaceae
(1) Gomphia serrata (Gaertn.) Kanis.

Plumbaginaceae

(1) Plumbago zeylanica L. Elanitul Chithravembu $\mathrm{H}^{+}$

Rhamnaceae

(1) Ventilago maderaspatana Gaertn.

(2) Zyzyphus oenoplia (L.) Mill.

Madan

Arugadam

$\mathrm{T}^{*}+$

Rubiaceae

(1) Canthium parvifolium Lam.

(2) Ixora arborea Roxb.

Yakadawel

Pappili

$\mathrm{L}^{+}$

Hin Eraminiya

Ambulam

$\mathrm{CS}^{+}$

(3) Lxora coccinea $\mathrm{L}$.

Godaratmal

T

Maharathambala

(4) Ixora thwaitesii Hook.

Ratmal

Vetchi

(5) Mytragyna parvifolia Roxb.

Halamba

Kadambai

Buthsarana

Vellaiyillai

Kukuruman

Karai

$\mathrm{T}$

$\mathrm{s}^{+}$

$\mathrm{s}$

(6) Mussaenda frondosa $\mathrm{L}$.

(7) Randia dumetorum Lam.

[Catunaregam spinosa (Thumb.)

Tirreng.]

(8) Tarenna asiatica L.

Tharenna

Karanai

Galseru

$\mathrm{T}^{+}$

(9) Tricalysia erythrospora Thw.

Galseru

Rutaceae

(1) Atalantia ceylanica (Arn.) Oliv.

Wal dehi

Pey-Kurundu

Burutha

(3) Clausena indica Burm.

Megon

Purusamarum

Pannai

$\mathrm{H}^{+}$

$\mathrm{T}^{+}$

karapincha

(4) Glycosmis angustifolia Lindl.

Bol-pana

$\mathrm{T}^{+}$

$T^{*}+$ $\mathrm{T}^{+}$

$\mathrm{S}^{+}$

$\mathrm{s}^{+}$ 
Table 1a Contd.

\begin{tabular}{|c|c|c|c|}
\hline Family and Species & Sinhala name & Tamil name & Life form \\
\hline (5) Micromelum ceylanicum Swingle. & Wal karapincha & Kakkaipalai & $s^{+}$ \\
\hline (6) Pleiospermium alatum (Wight \& & Thumpath & Mylaidi & $S^{+}$ \\
\hline Arn.) Swingle. & kurundu & kurundu & \\
\hline (7) Toddalia asiatica (L.) Lam. & Kudumiris & Kuttumilagu & $\mathrm{H}^{+}$ \\
\hline \multicolumn{4}{|l|}{ Sapindaceae } \\
\hline (1) Allophylus cobbe (L.) Bl. & Kobbe & Amlai & $s^{+}$ \\
\hline (2) Aphania bifoliata Thw. & Galkuma & Katkuma & $\mathrm{T}$ \\
\hline (3) Dimocarpus longan Lour. & Mora & & $\mathrm{T}^{+}$ \\
\hline $\begin{array}{l}\text { (4) Lepisanthus tetraphylla (Vahl.) } \\
\text { Radlk. }\end{array}$ & Dambu & Nuna & $\mathrm{T}$ \\
\hline \multicolumn{4}{|l|}{ Sapotaceae } \\
\hline $\begin{array}{l}\text { (1) Manilkara hexandra Roxb. } \\
\text { Sterculiaceae }\end{array}$ & Palu & Pasipayaru & $\mathrm{T}^{+}$ \\
\hline $\begin{array}{l}\text { (1) Pterospermum canescens Roxb. } \\
\text { [Pterospermum suberifolium Lam.] }\end{array}$ & Welanga & Thetti & $\mathrm{T}^{+}$ \\
\hline \multicolumn{4}{|l|}{ Tiliaceae } \\
\hline (1) Grewia microcos L. & Keliya & & $\mathrm{C}^{+}$ \\
\hline $\begin{array}{l}\text { (2) Grewia polygama Roxb. } \\
\text { [Grewia rothii A.DC.] }\end{array}$ & Boradaminiya & Thavattai & $\mathrm{T}^{+}$ \\
\hline \multicolumn{4}{|l|}{ Verbenaceae } \\
\hline (1) Lantana camara var. aculeata (L.) & Gandapana & & $S^{+}$ \\
\hline (2) Premna tomentosa Willd. & Bu-seru & Kolkutthi & $S^{+}$ \\
\hline (3) Vitex altissima L. & Milla & & $\mathrm{T}^{+}$ \\
\hline \multicolumn{4}{|l|}{ Vitaceae } \\
\hline (1) Cissus heyneana Wall. & Nil wel & & LC \\
\hline
\end{tabular}

Table 1b: The medicinal uses of some species found in the understorey vegetation (DBH $<10 \mathrm{~cm}$ ) of the studied area of a Tropical Dry Mixed Evergreen Forest.

\begin{tabular}{ll}
\hline Family and Species & Medicinal use \\
\hline $\begin{array}{l}\text { Acanthaceae } \\
\text { Blepharis edulis Pers. }\end{array}$ & $\begin{array}{l}\text { Astringent to bowels, diuretic, aphrodisiac, } \\
\text { treatment of leucoderma and healing of } \\
\text { wounds and ulcers. }\end{array}$ \\
$\begin{array}{l}\text { Asclepiadaceae } \\
\text { Warcostemma brunonianum \& Arn }\end{array}$ & $\begin{array}{l}\text { Treatment of fractures, stomochic tonic, } \\
\text { chologogue laxative, diuretic, stimulates } \\
\text { appetite and improves digestion. }\end{array}$ \\
$\begin{array}{l}\text { Cucurbitaceae } \\
\text { Bryonopsis laciniosa L. }\end{array}$ & $\begin{array}{l}\text { Purgative, leaves are applied on } \\
\text { inflammations. }\end{array}$ \\
\hline
\end{tabular}


Table $1 b$ Contd.

\begin{tabular}{ll}
\hline Family and Species & Medicinal use \\
\hline Euphorbiaceae & Diuretic and purgative \\
Fimorphocalyx glabellus Thw. & $\begin{array}{l}\text { Teucopyrus Willd. } \\
\text { The juice of the leaves is used to destroy maggots } \\
\text { in sores }\end{array}$
\end{tabular}

Fabaceae

Albizia amara (Roxb.) Boivin Seed astringent, treatment in gonorrhoea, heamorrhoids, diarrhoea. Flowers are externally applied to inflammated boils and ulcers. Leaves are used in ophthalmia.

Bauhinia tomentosa $\mathrm{L}$.

Treatment of acute and chronic diarrhoea and dysentery internal haemorrhages and bleeding from haemorrhoids. Bark is applied on tumours and wounds. Fruit is a diuretic and seed is aphrodisiac and is used for wounds inflicted by poisonous animals.

Cassia fistula $\mathrm{L}$.

The bark and roots are used for rheumatism, malaria. Leaves and fruits are purgative. A decoction of flowers is used for rat-bite poisoning. Leaves and bark are used to apply on insect bites, rhcumatism, facial paralysis, leprosy, eczema and psoriasis.

Derris uliginosa Willd.

Treatment of rheumatism and dysmenorrhoea.

Flacourtiaceae

Flacourtia indica

Fruits are used for the treatment of jaundice and enlarged spleen. Gum is used in the treatment of cholera.

Hypoxidaceae

Curculigo orchioides Gacrtn. Roots are used in the treatment for piles, jaundice, asthma, and diarrhoea. Tonic and aphrodisiac.

$\underline{\text { Loganiaceae }}$

Strychnos Nux-vomica L.

Leaves are applied on ulcers. Bark is used as a tonic for dyspepsia and diarrhoea.

Malphigiaceae

Hiptage benghalensis $\mathrm{L}$.

Leaves are used in the treatment of chronic rheumatism, skin diseases and asthma, and applied for scabies.

Melastomataceae

Memecylon umbellatum Burm. f. A decoction of the root is used for irregular menstruation and an infusion of the leaves is used as an astringent for ophthalmia. 
Table 1b Contd.

\begin{tabular}{ll}
\hline Family and Species & Medicinal use \\
\hline Meliaceae &
\end{tabular}

Azadirachta indica A. Juss. A decoction of leaves is antiseptic and is used for washing wounds, ulcers and as a bath for patients recovering from chickenpox and childbirth. Gummy exudation is used in catarrhal ailments. The sap is used for leprosy and skin disease, and also externally for rheumatism and internally for chronic malarial fever.

Aglaia roxburghiana

Wight \& Arn. (Miq).

Menispermaceae

Cissampelos pareira $\mathrm{L}$.

\section{Myrtaceae}

Syzygium cumini (L) Skeels

Plumbaginaceae

Plumbago zeylanica L.

Rhamnaceae

Ventilago maderaspatana

Gaertn.

Zyzyphus oenoplia (L.) Mill.

Rubiaceae

Liora coccinea $\mathrm{L}$.
Root and bark are used for dysentery and fever, and leaves for abdominal pains. Fruits are used for haemoptysis, diarrhoea with vomiting and externally on ulcers.

Leaves are used as an antiscabious remedy, and for absesses, ulcers and wounds. A decoction of root is a fcbrifuge, diuretic, lithostrific and pectoral remedy. Plant is emetic and purgative, and it is also used in the treatment of chronic cystitis, nephritic, colic, nephritis, vascular calculus, fever, diarrhoea and urinary and venereal diseases.

A decoction of the bark is used internally for diarrhoea and dysentery, clearing ulcers, as a mouthwash for spongy gums. Fruit is used in the treatment of enlarged spleen, diarrhoea and diabetes.

Bark is a powerful sudorific and antiperiodic. Root is used in the treatment of skin diseases, diarrhoea, dyspepsia and anasarca. Juice is applied in scabies and ulcers.

The root bark is a tonic, carminative, stomachic and stimulant. Plant is used externally for skin diseases.

A decoction of the bark is used to promote the healing of fresh wounds. A conjee of all parts is used to counteract wasp stings.

A decoction of the root is used for dysentery, and as a sedative for hiccoughs, nausea, fever and gonorrhoea. It is also used as an appetiser. 
Table 16 Contd.

\begin{tabular}{l} 
Family and Species \\
\hline Mytragyna parvifolia Roxb. \\
Mussaenda frondosa $\mathrm{L}$. \\
Randia dumetonum Lam. \\
[Calunaregam spinosa \\
(Thumb.) Trireng.]
\end{tabular}

Tarenna asiatica $\mathrm{L}$.

$\underline{\text { Rutaceae }}$

Atalantia ceylanica (Arn.) Oliv. Leaves are used for cattarrh, bronchitis and chest

Chloroxylon swietenia DC.

Clausena indica Burm.

Micromelum ceylanicum
Swingle.

Toddalia asiatica (L.) Lam.

\section{$\underline{\text { Sapindaceae }}$}

Allophylus cobbe (L.) Bl.

Dimocarpus longan Lour.

\section{Sapotaceae}

Manilkara hexandra Roxb.

$\underline{\text { Tiliaceae }}$

Grewia microcos $\mathrm{L}$.
Medicinal use

A decoction of the root and bark is used for fever and colitis.

The root is used for white leprosy, sepals for jaundice, flowers for asthma, intermittent fever and dropsy, and all parts of the plant for hepatitis.

A decoction of the root is used for diarrhoea and biliousness. The bark is used in the treatment of fever and externally on bruises. The fruit is anthelmintic and used as an emetic for snake-bite poisoning.

The fruit is used for boils and promote suppuration. pains. Root is used for ague.

Bark is astringent. Leaves are applied to wounds and rheumatism.

An infusion of the stem is used for colic and diarrhoea. Leaves and roots are used for indigestion and as a diuretic.

All parts are used as tonic and stomachic. Leaves are used for constipation, abdominal colic, diarrhoea, dysentery, hiccough and hoarseness. Leaves are applied externally on eruptions.

Root is used as an anti malarial remedy and also as an anti pyretic, and an anti diarrhoeic. An infusion of root is a stimulating tonic. Fruit and root are used for rheumatism.

Plant is used as an emenogogue, and root for diarrhoea. All parts are used in oils for fractures.

A decoction of bark is given for rheumatism, swellings, diseases of lungs. Fruit is used for nutrient stomachic and anthelmintic.

Bark is used as an astringent.

Plant is used for indigestion, typhoid fever, dysentery and syphilitic ulceration of the mouth and in smallpox, eczema and itches. 
Table $1 b$ Contd.

\begin{tabular}{|c|c|}
\hline Family and Species & Medicinal use \\
\hline $\begin{array}{l}\text { Grewia polygama Roxb. } \\
\text { [Grewia rothii A.DC.] }\end{array}$ & $\begin{array}{l}\text { Root is used for diarrhoea, dysentery and is } \\
\text { externally applied to hasten suppuration and as a } \\
\text { dressing for wounds. }\end{array}$ \\
\hline \multicolumn{2}{|l|}{ Verbenaceae } \\
\hline Lantana camara var. aculeata (L.) & $\begin{array}{l}\text { A decoction is given in tetanus, rheumatism, } \\
\text { malaria, and in atoxy of abdominal viscera. }\end{array}$ \\
\hline Premna tomentosa Willd. & $\begin{array}{l}\text { An aromatic oil extracted from root is used for } \\
\text { stomach disorders. }\end{array}$ \\
\hline Vitex altissima $\mathrm{L}$. & $\begin{array}{l}\text { Fried in cow ghee and red onions are eaten for } \\
\text { painful micturition. }\end{array}$ \\
\hline
\end{tabular}

The quantitative data for the two categories were recorded and analyzed separately. Table 2 shows the density, relative density, percentage frequency and relative frequency of each species of the category 1. Accordingly, Glycosmis angustifolia of the Rutaceae attained the highest density of 162.5 per $100 \mathrm{~m}^{2}$ and the highest percentage frequency of 70.6. The second highest was Polyalthia korinti of the Annonaceae which possessed a density of $24.6 \mathrm{per} 100 \mathrm{~m}^{2}$ and a percentage frequency of 13.5. The third highest density and percentage frequency recorded represented Diospyros ovalis of the Ebenaceae i.e. 9.7 per $100 \mathrm{~m}^{2}$ and 8.6 respectively. The rest of the species showed comparatively low values for density and frequency. Salacia reticulata, Hiptage benghalensis, Ventilago maderaspatana and Derris uliginosa represented the liana species located in category 1.

Table 3 shows the density, relative density, percentage frequency and relative frequency of each species of the category 2 of which plants DBH $<10 \mathrm{~cm}$ and below $1 \mathrm{~m}$ in height. Accordingly, younger plants of the Glycosmis angustifolia were the dominants in the shorter stratum. This species reached a density of 33.1 per $100 \mathrm{~m}^{2}$ and a percentage frequency of 20.1. However, the values are lower than that of the category 1. Scleria lithosperma in the family Cyperaceae reached a density of 29.4 per $100 \mathrm{~m}^{2}$ and a percentage frequency of 13.1. Saplings and seedlings of Aphania bifoliata in the family Sapindaceae showed the next highest density of 23.2 per $100 \mathrm{~m}^{2}$ and percentage frequency of 12.9. Younger plants of Diospyros spp. in the family Ebenaceae attained the third highest density of 18.9 per $100 \mathrm{~m}^{2}$ and frequency of 14.6 . However, some smaller plants of the genus Diospyros were collectively recorded as it was unable to identify them to their species level. But all the other species showed relatively low densities and frequencies. Some graminoides were also found especially in exposed areas, within the forest. Seedlings and saplings of other species such as Vitex altissima, Alseodaphne semecarpifolia, Chloroxylon swietenia, Syzygium cumini and Grewia polygama were also found in this ground layer, though their abundance was very low (Tables $2 \& 3$ ). The relative density and relative frequency of each species followed the same pattern as that of its density and percentage frequency. Categories (Tables 2\&3). 
Table 2: The density (number of individuals per $100 \mathrm{~m}^{2}$ ), relative density, percentage frequency and relative frequency of species below $10 \mathrm{~cm} \mathrm{DBH}$ and above $1 \mathrm{~m}$ in height (Category 1 ) found in the understorey vegetation of the studied area of tropical lowland seasonal rain forest. (Each value is a mean of 10 replicates).

\begin{tabular}{|c|c|c|c|c|}
\hline Family and Species & $\begin{array}{c}\text { Density } \\
\text { individuals/ } \\
-100 \mathrm{~m}^{2}\end{array}$ & $\begin{array}{l}\text { Relative } \\
\text { density }\end{array}$ & $\begin{array}{l}\text { Percentage } \\
\text { frequency }\end{array}$ & $\begin{array}{l}\text { Relative } \\
\text { frequency }\end{array}$ \\
\hline \multicolumn{5}{|l|}{ Annonaceae } \\
\hline$\overline{\text { Miliusa indica }}$ & 7.2 & 2.73 & 6.2 & 4.03 \\
\hline Polyalthia spp. & 1.2 & 0.45 & 1.1 & 0.54 \\
\hline Polyalthia korinti & 24.6 & 9.32 & 13.5 & 8.72 \\
\hline Polyalthia suberosa & 0.7 & 0.27 & 0.7 & 0.46 \\
\hline \multicolumn{5}{|l|}{ Asclepiadaceae } \\
\hline Sarcostemma brunonianum & 2.3 & 0.87 & 2.3 & 1.56 \\
\hline Tylophora tenuissima & 0.1 & 0.04 & 0.1 & 0.07 \\
\hline Boraginaceae & & & & \\
\hline Cordia spp. & 0.1 & 0.04 & 0.1 & 0.07 \\
\hline Ebenaceae & & & & \\
\hline Diospyros spp. & 2.4 & 0.91 & 1.3 & 0.85 \\
\hline Diospyros ovalifolia & 9.7 & 3.67 & 8.6 & 5.59 \\
\hline \multicolumn{5}{|l|}{ Euphorbiaceae } \\
\hline Drypetes sepiaria & 0.2 & 0.08 & 0.2 & 0.13 \\
\hline Mallotus albus & 1.7 & 0.64 & 1.6 & 1.04 \\
\hline Phyllanthus polyphyllus & 1.8 & 0.61 & 1.6 & 1.04 \\
\hline \multicolumn{5}{|l|}{ Fabaceae } \\
\hline Derris uliginosa & 1.2 & 0.45 & 1.2 & 0.78 \\
\hline \multicolumn{5}{|l|}{ Hippocrateaceae } \\
\hline \multicolumn{4}{|l|}{$\underline{\text { Lauraceae }}$} & 1.82 \\
\hline $\begin{array}{l}\text { Alseodaphne semecarpifolia } \\
\text { Malpighiaceae }\end{array}$ & 3.9 & 1.48 & 3.9 & 2.54 \\
\hline Hiptage benghalensis & 0.8 & 0.30 & 0.7 & 0.46 \\
\hline \multicolumn{5}{|l|}{ Melastomataceae } \\
\hline Memecylon umbellatum & 0.2 & 0.04 & 0.2 & 0.07 \\
\hline \multicolumn{5}{|l|}{ Meliaceae } \\
\hline Aglaia roxbunghiana & 1.3 & 0.49 & 1.3 & 0.85 \\
\hline \multicolumn{5}{|l|}{ Myrtaceae } \\
\hline Syzygium cumini & 7.0 & 2.65 & 6.3 & 4.10 \\
\hline
\end{tabular}


Table 2 Contd.

\begin{tabular}{|c|c|c|c|c|}
\hline Family and Species & $\begin{array}{l}\text { Density } \\
\text { individuals/ } \\
-100 \mathrm{~m}^{2}\end{array}$ & $\begin{array}{l}\text { Relative } \\
\text { density }\end{array}$ & $\begin{array}{l}\text { Percentage } \\
\text { frequency }\end{array}$ & $\begin{array}{l}\text { Relative } \\
\text { frequency }\end{array}$ \\
\hline \multicolumn{5}{|l|}{ Ochnaceae } \\
\hline Gomphia serrata & 5.7 & 2.16 & 4.5 & 2.93 \\
\hline \multicolumn{5}{|l|}{ Rhamnaceae } \\
\hline Ventilago maderaspatana & 0.5 & 0.19 & 0.5 & 0.33 \\
\hline Zyzyphus oenoplia & 1.3 & 0.49 & 1.3 & 0.85 \\
\hline \multicolumn{5}{|l|}{ Rubiaceae } \\
\hline Mussaenda frondosa & 0.1 & 0.04 & 0.1 & 0.07 \\
\hline Randia dumetorum & 2.1 & 0.80 & 2.1 & 1.37 \\
\hline Tarena asiatica & 0.1 & 0.04 & 0.1 & 0.07 \\
\hline Trycalysia erythrospora & 0.2 & 0.08 & 0.2 & 0.13 \\
\hline \multicolumn{5}{|l|}{ Rutaceae } \\
\hline$\overline{\text { Atalantia }}$ ceylanica & 3.7 & 1.40 & 3.7 & 2.41 \\
\hline Chloroxylon swietenia & 1.7 & 0.64 & 1.6 & 1.04 \\
\hline Clausena indica & 0.1 & 0.04 & 0.1 & 0.07 \\
\hline Glycosmis angustifolia & 162.5 & 61.55 & 70.6 & 45.90 \\
\hline $\begin{array}{l}\text { Pleiospermium alatum } \\
\text { Sapindaceae }\end{array}$ & 0.2 & 0.08 & 0.2 & 0.13 \\
\hline$\overline{\text { Allophylus cobbe }}$ & 0.4 & 0.15 & 0.4 & 0.26 \\
\hline Aphania bifoliata & 7.1 & 2.69 & 6.0 & 3.90 \\
\hline Dimocarpus longan & 2.3 & 0.87 & 2.2 & 1.43 \\
\hline \multicolumn{4}{|l|}{ Sterculiaceae } & 1.17 \\
\hline$\overline{\text { Pterospermum canescens }}$ & 2.2 & 0.83 & 2.2 & 1.43 \\
\hline \multicolumn{5}{|l|}{ Tiliaceae } \\
\hline Grewia microcos & 0.2 & 0.08 & 0.2 & 0.13 \\
\hline Grewia polygama & 0.5 & 0.19 & 0.5 & 0.33 \\
\hline \multicolumn{5}{|l|}{ Verbenaceae } \\
\hline Vitex altissima & 0.8 & 0.30 & 0.8 & 0.52 \\
\hline \multicolumn{5}{|l|}{ Unidentified Species } \\
\hline 1. & 0.1 & 0.15 & 0.1 & 0.26 \\
\hline 2. & 0.4 & 0.15 & 0.2 & 0.07 \\
\hline 3. & 0.1 & 0.04 & 0.1 & 0.13 \\
\hline 4. & 0.1 & 0.04 & 0.1 & 0.07 \\
\hline 5. & 0.4 & 0.04 & 0.1 & 0.07 \\
\hline 6. & 0.1 & 0.04 & 0.1 & 0.07 \\
\hline
\end{tabular}


Table 3: The density (number of individuals per $100 \mathrm{~m}^{2}$ ), relative density, percentage frequency and relative frequency of species below $10 \mathrm{~cm} \mathrm{DBH}$ and below $1 \mathrm{~m}$ in height (category 2) found in the understorey vegetation of the studied area of a tropical lowland seasonal rain forest. (Each value is a mean of 10 replicates).

\begin{tabular}{|c|c|c|c|c|}
\hline Family and Species & $\begin{array}{c}\text { Density } \\
\text { individuals/-1 } \\
00 \mathrm{~m}^{2}\end{array}$ & $\begin{array}{l}\text { Relative } \\
\text { density }\end{array}$ & $\begin{array}{l}\text { Percentage } \\
\text { frequency }\end{array}$ & $\begin{array}{l}\text { Relative } \\
\text { frequency }\end{array}$ \\
\hline \multicolumn{5}{|l|}{ Annonaceae } \\
\hline$\overline{\text { Miliusa indica }}$ & 1.30 & 0.77 & 1.20 & 1.12 \\
\hline Polyalthia spp. & 4.20 & 2.49 & 2.20 & 2.06 \\
\hline Polyalthia korinti & 5.00 & 2.96 & 4.20 & 3.94 \\
\hline $\begin{array}{l}\text { Polyalthia suberosa } \\
\text { Asteraceae }\end{array}$ & 0.90 & 0.53 & 0.80 & 0.75 \\
\hline $\begin{array}{l}\text { Elephantopus scaber } \\
\text { Boraginaceae }\end{array}$ & 0.10 & 0.06 & 0.10 & 0.09 \\
\hline $\begin{array}{l}\text { Cordia spp. } \\
\text { Cyperaceae }\end{array}$ & 0.10 & 0.06 & 0.10 & 0.09 \\
\hline $\begin{array}{l}\text { Scleria lithosperma } \\
\text { Dioscoreaceae }\end{array}$ & 29.40 & 17.43 & 13.10 & 12.28 \\
\hline $\begin{array}{l}\text { Trichopus zeylanicus } \\
\text { Ebenaceae }\end{array}$ & 1.30 & 0.77 & 0.30 & 0.28 \\
\hline$\overline{\text { Diospyros spp. }}$ & 18.90 & 11.20 & 14.60 & 13.68 \\
\hline $\begin{array}{l}\text { Diospyros ovalifolia } \\
\text { Euphorbiaceae }\end{array}$ & 4.50 & 2.67 & 3.60 & 3.37 \\
\hline$\overline{\text { Flueggea leucopyrus }}$ & 0.30 & 0.18 & 0.30 & 0.28 \\
\hline Mallotus albus & 5.80 & 3.44 & 4.60 & 4.31 \\
\hline $\begin{array}{l}\text { Phyllanthus polyphyllus } \\
\text { Fabaceae }\end{array}$ & 0.20 & 0.12 & 0.20 & 0.19 \\
\hline$\overline{\text { Cassia fistula }}$ & 0.20 & 0.12 & 0.10 & 0.09 \\
\hline $\begin{array}{l}\text { Derris uliginosa } \\
\text { Hippocrateaceae }\end{array}$ & 0.10 & 0.59 & 0.80 & 0.75 \\
\hline $\begin{array}{l}\text { Salacia reticulata } \\
\text { Lauraceae }\end{array}$ & 0.50 & 0.30 & 0.40 & 0.37 \\
\hline $\begin{array}{l}\text { Alseodaphne semecarpifolia } \\
\text { Loganiaceae }\end{array}$ & 2.22 & 1.30 & 2.20 & 2.06 \\
\hline $\begin{array}{l}\text { Strychnos nux-vomica } \\
\text { Meliaceae }\end{array}$ & 0.50 & 0.30 & 0.50 & 0.47 \\
\hline $\begin{array}{l}\text { Aglaia roxburghiana } \\
\text { Myrtaceae }\end{array}$ & 0.90 & 0.05 & 0.80 & 0.75 \\
\hline Syzygium cumini & 3.40 & 2.02 & 2.90 & 2.72 \\
\hline
\end{tabular}


Table 3 Contd.

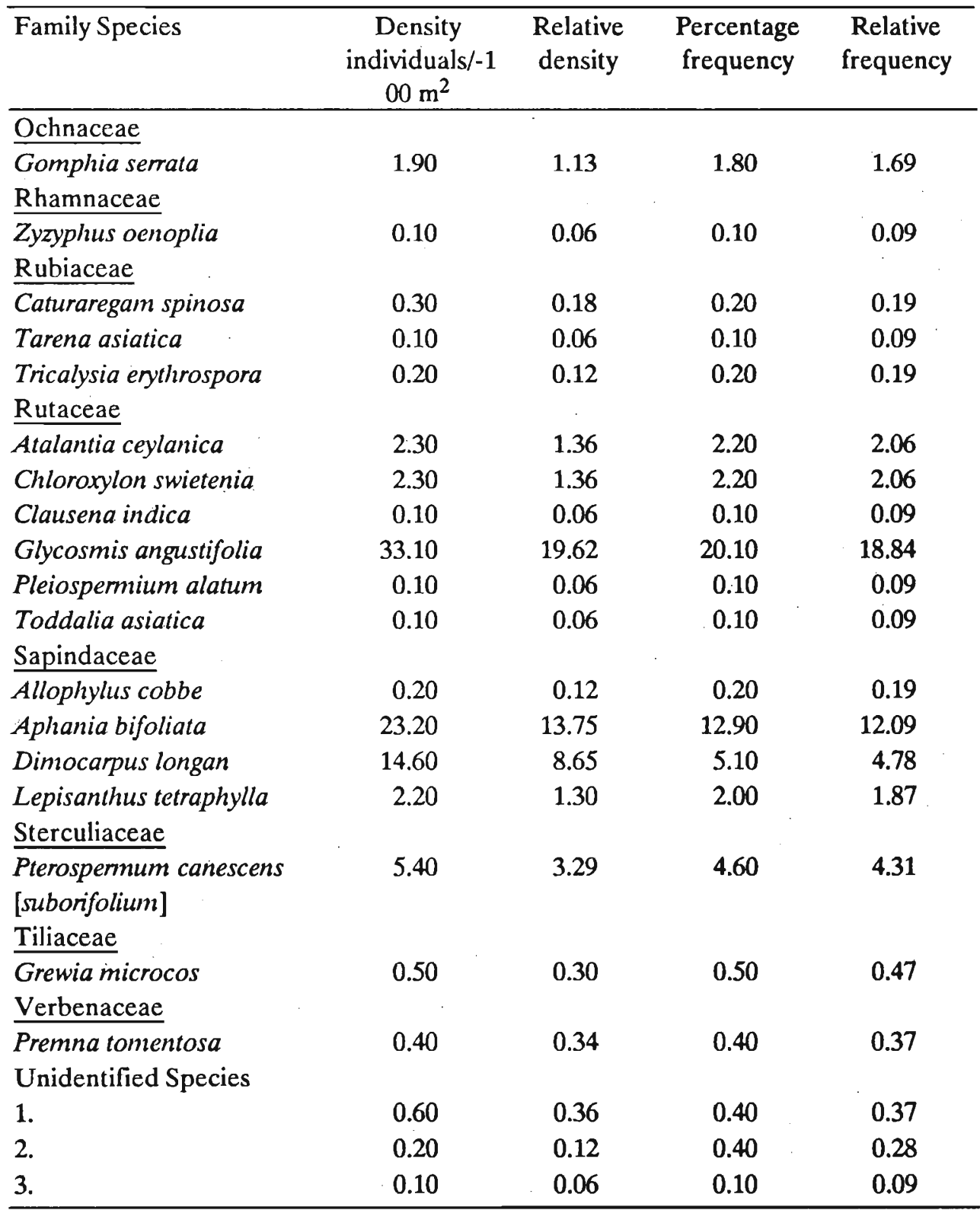

\section{DISCUSSION}

Tropical Dry Mixed Evergreen forest is the dominant formation in the dry zone lowlands of Sri Lanka. From the results it was evident that the understorey was dominated by the families Rubiaceae, Euphorbiaceae and Rutaceae. The importance of the understorey of the forest from its regeneration point of view is quite clear as the majority of its undeveloped representatives of species (i.e. about $46 \%$ ) were 
found to be undeveloped canopy tree species. If high canopied trees are dead due to natural or unnatural causes, some of their smaller individuals may increase their growth rate and could later occupy the canopy layer. The presence of $6 \%$ endemic species and $61 \%$ of medicinally important species further reveals the importance of the forest understorey. The average number of individuals per $100 \mathrm{~m}^{2}$ was 431 and about $61 \%$ of them belong to category 1 , and the rest belong to the category 2 . Therefore, the majority of individuals was found in the category 1 . The less abundance of individuals in category 2 may be due to change in quality and quantity of light on the forest floor. ${ }^{24}$

The analysis of the data under two categories as based on the DBH and height of plants has made this study more meaningful and useful. Taller and shorter plants of the understorey have different ecological impacts on the environment. The plants belonging to category 1 (higher stratum) being of greater height and having larger numbers may exert a greater influence on the growth of plants found in lower category 2 (shorter stratum). The abundance of each species (Tables $2 \& 3$ ) clearly indicates that there were many more species of very low abundance classes than the species of greater abundance classes. Approximately $99 \%$ of the species in category 1 were found very low abundance (below 25 individuals per $100 \mathrm{~m}^{2}$ ), whilst only $1 \%$ of them showed very high abundance (above 160 individuals per $100 \mathrm{~m}^{2}$ ).

The abundance of the most dominant species in the category 2 was very much lower than that in category 1 . This observation showed that the understorey of the forest was mainly dominated by a single species, Glycosmis angustifolia which represented about $45 \%$ of the individuals of the understorey. Approximately 196 individuals of this species per $100 \mathrm{~m}^{2}$ were found and about $83 \%$ of them were found in the category 1 and $17 \%$ was found in the category 2 . This species, accordingly, may be the most effective factor controlling the growth and distribution of the other species in the understorey of this forest. Its greater abundance could be attributed to many reasons. The environmental conditions such as light may be optimal for the growth of this species. It could also be possible that the reproductive potential of the species is greater than that of other species of the understorey.

Generally, the abundance of other tree species was found to be very low in the understorey. e.g. Diospyros species was scarce (about 12 individuals per $100 \mathrm{~m}^{2}$ ) in the higher stratum (category 1), but it was more abundant (about 24 individuals per $100 \mathrm{~m}^{2}$ ) in the lower stratum (category 2). Saplings of Drypetes sepiaria too were scarce in the understorey. However, the canopy layer is reported to be dominated by this species in a different area of the same formation at Polonnaruwa sanctuary. ${ }^{9}$ Perhaps this could be due to unsuitable environmental conditions prevailing in the understorey for the germination of seeds and further growth of the plants of these species. The main factor among these may be light. The canopy tree species may be light demanding; and it may be suggested that unless an open area is created, these small plants may remain small with a very slow growth rate, and their seeds may remain dormant in the soil. 
Some of the species listed in Table 1a were mainly found in open areas within the forest and also at edges. e.g. Vernonia zeylanica, Lxora coccinea and Plumbago zeylanica. These may be the invasive species.

The present study has been carried out during the dry season. A slight variation in species composition would have been observed if the study had been carried out during the rainy season, due to germination of some ephemeral species. However, the results of the present study would be useful in forest conservation, reforestation, aforestation and in agro-forestry programmes. They would also be of help in studying the succession of species in the understorey of a forest of the dry zone lowlands.

\section{Acknowledgement}

We thank the co-ordinators of the Kelaniya- Calgary Link programme, Prof. I. Balasooriya and Prof. D. Parkinson for providing support, Dr A.H.M Jayasuriya, Systematic Botanist, National Herbarium, and the Ayurvedic Research Institute, Sri Lanka, for help in the identification of species and colleagues in the Department of Botany who assisted in various ways.

\section{References}

1. Anon (1986). Forestry Master Plan for Sri Lanka. Main report. Jaakko Poyry International Oy. Unpublished field doccument. Helsinki.

2. Chapman V.J. (1947). The application of aerial photography to ecology as exemplified by the natural vegetation of Ceylon. Ind. for, 73, 257-314, (Cited in Biogeography, (1975), 2:185-203.

3. Rosayro R.A. de, (1950). Ecological conception and vegetational types with special reference to Ceylon. The Tropical Agriculturist 56(3):108-121.

4. Holmes C.H. (1956). The broad pattern of climatic and vegetational distribution in Ceylon. The Ceylon Forester 2(4):207-22.

5. Koelmeyer K.O. (1957). Climatic classification and the distribution of vegetation in Ceylon, The Ceylon Forester 3(2):144-163.

6. Andrews J.R.T. (1961). A forest inventory of Ceylon. Government press, Colombo. 116p In The Sri Lanka Forester (1980). XIV 102-212. 16.

7. Gaussen H.P., Legris M.V. \& Labroue L. (1964). International map of the vegetation; Ceylon $(1: 1,000,000)$. French Institute of Ponichery, India. In The Sri Lanka Forester XIV:(1980).

8. Perera N.P. (1968). Some problems of climatic vegetation correlations in Ceylon. Vidyodaya Journal of Arts and Science Letters 1:173-184.

9. Dittus W.P.J. (1985). The influence of cyclones on the dry evergreen forests of Sri Lanka. Biotropica 17(1):1-14. 
10. Gunatilleke C.V.S. \& Ashton P.S. (1987). New light on the plant geography of Ceylon, II. The ecological biogeography of the lowland endemic tree flora. Joumal of Biogeography 14:295-327.

11. Gunatilleke C.V.S., Gunatilleka I.A.U.N. \& Sumithraarachchi B. (1987). Woody endemic species of the Wet lowlands of Sri Lanka and their conservation in Botanic Gardens. In Botanic Gardens and the World Conservation strategy (Eds. D. Bramwell, O. Hamman, V.H. Heywood \& H. Synge). pp. 186-96. Academic Press, London.

12. Gunatilleke I.A.U.N. \& Gunatilleke C.V.S. (1991). Threatened woody endemics of the wet lowlands of Sri Lanka and their conservation. Biological Conservation 55:17-36.

13. Balsubramaniam S. \& Andrews M.G., (1980). A preliminary floristic-climatic classification of the forests of Sri Lanka. The Sri Lanka Forester 14(3\&4):163-169.

14. Jayasuriya A.H.M. (1981). Flora of Ritigala Natural Forest Reserve. The Sri Lanka Forester XIV:61-155.

15. Sathurusinghe A. (1985). Phytosociological Analysis of vegetation of Wilpattu National Park, M.Sc. Thesis, University of Sri Jayawardenapura, Gangodawila, Nugegoda, Sri Lanka.

16. Sumithrarachchi D.B. (1989). Sri Lankan forests diversity and genetic resources, In Tropical forests-Botanical Dynamics pp. 254-258.

17. Nanayakkara A., Parkinson D., Widanapathirana S. \& Balasooriya I. (1987). Litter production in a Dry Mixed Evergreen forest of Sri Lanka. Proceedings of the 43rd Annual Session of the Sri Lanka Association for the Advancement of Science pp.155.

18. Peeris C.V.S. (1975). The ecology of endemic tree species in relation to their conservation. Ph.D. Thesis. University of Aberdeen.

19. Trimen H. \& Hooker J.D. (1893-1990). A Handbook to the Flora of Ceylon. Parts 1-5. Dulav, London.

20. Dassanayake M.D. \& Fosberg F. R. (1980 - continuing). A revised handbook to the Flora of Ceylon, I-VI. Amarind Publishing Co., New Delhi.

21. Jayaweera D.M.A. (1982). Medicinal plants (indigenous and exotic) used in Ceylon. Parts 1-5. National Science Council of Sri Lanka, Colombo.

22. Kersheaw K.A. (1975). Quantitative and Dynamic Plant Ecology, (Second edition) Edward Arnold (Publishers) Ltd. London.

23. Smith R.L. (1966). Ecology and Field Biology. Harper \& Row, New York.

24. Mitchell P.L. (1984). Solar radiation under coppice and the physiological ecology of selected woodland plants. Ph.D. Thesis, University of Cambridge. 